\title{
RESPONS IKAN ZEBRA EKOR HITAM (Dascyllus melanurus) TERHADAP PENGGUNAAN ANAESTESI MINYAK CENGKEH SEBAGAI ALAT BANTU PENANGKAPAN PADA SKALA LABORATORIUM
}

\author{
Response of Zebra Fish Blacktail (Dascyllus melanurus) on the use of Clove Oil Anesthesia \\ as a Tool for Catching in Laboratory Scale
}

\author{
Oleh: \\ Sri Wahyuni Rahim ${ }^{*}$ \\ ${ }^{1}$ Jurusan Perikanan, Fakultas Ilmu Kelautan dan Perikanan, Universitas Hasanuddin \\ "Korespondensi:yunirahim@yahoo.co.id
}

Diterima: 04 Desember 2015; Disetujui: 18 November 2016

\begin{abstract}
The process of catching fish using an anesthetic technique is inseparable from the use of synthetic chemicals (cyanide) that negatively impact the target fish, non-target and on coral reefs. One way to reduce the negative impact of cyanide is to look for another alternative that are environmental friendly. One alternative is clove oil. The objectives of study are to determine the optimal concentration of clove oil on the induction and recovery time of zebra fish blacktail (Dascyllus melanurus). Samples used were captured without using cyanide. A tank with dimension $30 \times 40 \times 50$ m filled with sea water was mixed with different concentrations of clove oil. The experiment was repeated three times. Observation of the behavior was performed to determine the induction and recovery time. The results showed the longest induction time were observed in concentration of $20 \mathrm{ppm}$ with an average time of 321.33 seconds and the fastest time of induction was recognized in concentration of $60 \mathrm{ppm}$ with an average time of 28.33 seconds. Longest recovery time was at a concentration of $20 \mathrm{ppm}$ with an average time of 188.33 seconds and the fastest recovery time was at a concentration of $40 \mathrm{ppm}$ with an average time of 80.67 seconds. Clove oil concentration of 40 ppm was most effective in fishing with induction time ranged from 4048 seconds, and recovery time ranges from $72-91$ seconds.
\end{abstract}

Keywords: clove oil, induction time, recovery time, zebra fish blacktail

\begin{abstract}
ABSTRAK
Proses penangkapan ikan dengan menggunakan teknik pembiusan tidak terlepas dari penggunaan bahan kimia sintetik (sianida) yang berdampak negatif terhadap ikan target, nontarget serta pada terumbu karang. Salah satu cara untuk mengurangi dampak negatif dari sianida adalah dengan mencari alternatif lain yang ramah lingkungan. Salah satu alternatif yang digunakan adalah minyak cengkeh. Penelitian ini bertujuan untuk mengetahui konsentrasi optimal minyak cengkeh terhadap waktu induksi dan waktu pulih ikan zebra blacktail (Dascyllus melanurus). Sampel yang digunakan ditangkap tanpa mengggunakan sianida. Akuarium berukuran $30 \times 40 \times$ $50 \mathrm{~m}$ diisi dengan air laut. Kemudian dimasukkan beberapa konsentrasi minyak cengkeh yang berbeda $(20,30,40,50$ dan 60 ppm). Pengamatan terhadap tingkah laku dilakukan untuk menentukan waktu induksi dan waktu pulih. Hasil penelitian menunjukkan waktu induksi terlama terdapat pada konsentrasi 20 ppm dengan waktu rata-rata 321,33 detik dan waktu induksi tercepat terdapat pada konsentrasi $60 \mathrm{ppm}$ dengan waktu rata-rata 28,33 detik. Waktu pulih terlama terdapat pada konsentrasi 20 ppm dengan waktu rata-rata 188,33 detik dan waktu pulih tercepat
\end{abstract}


terdapat pada konsentrasi 40 ppm dengan waktu rata-rata 80,67 detik. Penelitian ini menunjukkan bahwa konsentrasi minyak cengkeh 40 ppm merupakan konsentrasi yang paling efektif dalam proses penangkapan ikan zebra blacktail (Dascyllus melanurus) dengan waktu induksi berkisar 40 - 48 detik dan waktu pulih berkisar $72-91$ detik.

Kata kunci: minyak cengkeh, waktu Induksi, waktu pulih, ikan zebra blacktail

\section{PENDAHULUAN}

Berdasarkan wawancara dengan nelayan pada saat survei pendahuluan, pembiusan merupakan salah satu cara penangkapan ikan yang sering dilakukan oleh nelayan di perairan Makassar, khususnya ikan-ikan yang hidup pada ekosistem terumbu karang. Setelah dibius, ikan akan keluar dari tempat persembunyiannya (terumbu karang), sehingga memudahkan nelayan dalam proses penangkapan.

Dalam proses pembiusan, nelayan umumnya menggunakan potassium sianida sebagai bahan anestesinya. Namun penggunaan sianida dalam proses penangkapan ikan hias berdampak negatif terhadap ikan target dan ikan non-target serta berdampak pada kerusakan terumbu karang yang sangat hebat. Rubec et al (2001) menyatakan bahwa ikan yang dipaparkan sianida akan mengalami sesak napas meskipun telah dipindahkan pada air laut yang bersih. Selain itu, penangkapan menggunakan sianida telah terbukti merusak ekosistem terumbu karang. Pemaparan sianida pada karang selama 10 menit mengalami kematian dalam waktu 7 hari, sedangkan pada konsentrasi yang rendah telah menyebabkan zooxanthellae yang bersimbiosis dalam karang lepas dan kapasitas fotosintesis menjadi terganggu, yang dapat mengakibatkan karang akan mati selama periode waktu yang lebih lama (Jones dan Steven, 1997; Jones et al. 1999 dan Cervino et al. 2003). Oleh karena itu, perlu dicari alternatif obat bius pengganti sianida yang ramah lingkungan untuk membantu penangkapan ikan-ikan karang. Salah satu alternatif yang dapat dicoba untuk digunakan adalah minyak cengkeh. Minyak cengkeh yang berasal dari tanaman cengkeh mengandung eugenol (senyawa oksigenatid hidrokarbon) dan merupakan salah satu zat anastetik. Minyak cengkeh mempunyai beberapa kelebihan antara lain harganya relatif lebih murah, mudah dalam penggunaannya, dapat bekerja meskipun dalam konsentrasi yang lebih rendah, alami, dan yang lebih penting lagi mudah diperoleh karena cengkeh merupakan komoditas lokal yang cukup tinggi di Indonesia.

Penelitian-penelitian sebelumnya telah menunjukkan efektivitas minyak cengkeh untuk digunakan sebagai bahan bius dalam proses transportasi dan penanganan ikan dibanding obat bius yang lain, seperti yang telah dilaporkan pada rainbow trout (Oncorhynchus mykiss Walbaum (Keene et al. 1998), ikan karang Pomacentrus amboinensis Bleeker (Munday and Wilson 1997), channel catfish (Ictalurus punctatus Rafinesque) (Waterstrat 1999), dan ikan baronang (rabbitfish/ Siganus lineatus) (Soto dan Burhanuddin 1995). Namun, masih sangat sedikit penelitian yang dilakukan untuk tujuan penangkapan.

Ikan zebra blacktail (Dascyllus melanurus) merupakan salah satu jenis ikan hias yang hidup pada ekosistem terumbu karang dan merupakan salah satu ikan yang ditangkap oleh nelayan menggunakan bius sianida untuk ikan hias dalam akuarium air laut (hasil wawancara dengan nelayan). Hal inilah yang mendasari digunakannya ikan zebra blacktail sebagai sampel ikan hias air laut pada percobaan ini. Berkaitan dengan penggunaan minyak cengkeh terhadap respons tingkah laku ikan zebra blacktail (Dascyllus melanurus), maka dipandang perlu untuk mengamati waktu induksi dan waktu pulih ikan zebra blacktail (Dascyllus melanurus) pada konsentrasi minyak cengkeh yang berbeda. Penelitian ini bertujuan untuk menganalisis konsentrasi optimal minyak cengkeh terhadap waktu induksi dan waktu pulih ikan zebra blacktail (Dascyllus melanurus).

\section{METODE}

Penelitian dilakukan pada Bulan JuliAgustus 2014. Lokasi penelitian pada Hatcheri Fakultas IImu Kelautan dan Perikanan, Universitas Hasanuddin di Pulau Barrang Lompo, Makassar, Sulawesi Selatan.

Penelitian ini menggunakan hewan uji ikan zebra blacktail (Dascyllus melanurus) sebanyak 18 ekor (15 ekor ikan untuk eksperimen, 3 ekor ikan merupakan ikan kontrol). Ikan ini merupakan salah satu ikan hias yang sering bersembunyi di terumbu karang. Dalam penangkapan ikan ini, nelayan umumnya menggunakan sianida. Namun, dalam penangkapan ikan untuk sampel penelitian ini tidak menggunakan sianida dalam penangkapannya. Oleh karena itu, nelayan dipantau dalam proses penangkapannya. Ukuran ikan berkisar $8-10 \mathrm{~cm}$. Sebelum eksperimen dila- 
kukan, ikan sampel dikumpulkan di dalam bak penampungan selama 1 (satu) minggu. Hal ini dimaksudkan agar supaya sampel ikan tersebut dapat melakukan proses aklimatisasi Ikan sampel diberi pakan alami 2 (dua) kali sehari selama proses aklimatisasi. Proses penyiponan dilakukan sebelum pemberian pakan, hal ini bertujuan agar sisa pakan dan sisa metabolisme yang ada tidak mengganggu kehidupan ikan. Bak penampungan yang digunakan diberi aerasi dan sirkulasi air sepanjang waktu yang berasal dari perairan Pulau Barrang Lompo (suhu $29^{\circ} \mathrm{C}$; pH 7,8; Salinitas $30 \mathrm{mg} / \mathrm{L}$ ). Hewan uji dipuasakan selama 8-10 jam sebelum eksperimen dilakukan agar supaya ikan tidak mengalami muntah pada saat proses anaestesi.

Penelitian menggunakan 2 akuarium kaca yang berukuran $30 \times 40 \times 50$ m yang diisi air laut dengan volume 50 liter, ketebalan kaca $1 \mathrm{~mm}$, yang masing-masing dilengkapi dengan aerator. Satu akuarium untuk eksperimen induksi dan satu akuarium untuk pemulihan. Akuarium diisi dengan air laut yang berasal dari perairan Barrang Lompo. Kualitas air pada saat eksperimen yaitu suhu $29{ }^{\circ} \mathrm{C}$; $\mathrm{pH} 7,8$; Salinitas $30 \mathrm{mg} / \mathrm{L}$..

Kadar eugenol dalam minyak cengkeh adalah 83,058 \% (dianalisis dengan menggunakan metode kromatografi ion HPLC). Sebelum eksperimen, minyak cengkeh dilarutkan terlebih dahulu di dalam $95 \%$ ethanol dengan ratio $1: 8$ (Cho and Heath 2000). Kemudian larutan tersebut disemprotkan ke dalam akuarium dengan konsentrasi yang berbeda $(20,30,40,50,60$ ppm) berdasarkan hasil penelitian sebelumnya (Griffiths 2000; Cunha 2006; Rahim et al. 2013).

Pengamatan respons ikan dengan mengamati tingkah laku ikan sebelum dan setelah pemaparan minyak cengkeh menggunakan video camera. Pengamatan yang dilakukan meliputi gerakan ikan sebelum dipaparkan minyak cengkeh, tahapan-tahapan tingkah laku ikan setelah dipaparkan minyak cengkeh dan tahapan pulih setelah ikan dipindahkan ke akuarium pulih (Tabel 1). Kemudian membandingkan gerakan-gerakan (tingkah laku) ikan perlakuan (ikan yang dipaparkan minyak cengkeh dengan beberapa konsentrasi) dengan ikan kontrol untuk mengamati ada tidaknya perbedaan tingkah laku pada ikan sampel. Setiap perlakuan konsentrasi menggunakan ikan eksperimen yang berbeda.

Selajutnya dilakukan pengamatan terhadap waktu induksi dan waktu pulih. Penelitian ini menggunakan disain eksperimen Ran- cangan Acak Lengkap (RAL) untuk mengamati waktu induksi dan waktu pulih. Rancangan ini terdiri dari 5 perlakuan konsentrasi $(20,30,40$, 50 dan 60 ppm) dengan 3 kali pengulangan berdasarkan hasil penelitian Griffiths (2000), Cunha (2006) dan Rahim et al. (2013). Dua akuarium yang digunakan, masing-masing mengamati waktu induksi (yang dihitung mulai pada saat ikan disemprotkan dengan minyak cengkeh sampai ikan mengalami pingsan) dan waktu pulih (yang dihitung sesaat setelah pingsan sampai ikan kembali pulih) dengan ciriciri seperti pada Tabel 1. Ada dua buah Digital Video Camera yang diletakkan pada kedua sisi akuarium untuk mengamati respons tingkah laku ikan, waktu induksi dan waktu pulih ikan. Akuarium diisi dengan air laut sebanyak 50 liter kemudian dimasukkan ikan sampel kedalamnya lalu diamati gerakan-gerakan ikan sebelum dipaparkan minyak cengkeh (kontrol). Setelah itu, ikan sampel disemprot dengan minyak cengkeh pada konsentrasi yang berbeda, yaitu 20, 30, 40, 50, dan 60 ppm. Gerakan-gerakan ikan diamati mulai dari tahapan terpengaruh sampai ikan mengalami tahapan pingsan. Kemudian waktu mencapai setiap tahapan dihitung. Setelah mencapai tahapan pingsan, ikan kemudian diangkat lalu dipindahkan ke akuarium pulih, yaitu akuarium yang berisi air laut yang tidak terkontaminasi dengan minyak cengkeh. Dalam proses pemulihan, gerakangerakan ikan diamati sampai ikan tersebut bergerak dengan normal kembali (tahapan pulih) dan waktu mencapai tahapan pulih dihitung. Selanjutnya efektivitas minyak cengkeh dianalisis berdasarkan Marking and Meyer (1985).

Analisis data dilakukan dengan menggunakan perangkat lunak MS Excel dan SPSS. Uji tingkat signifikansi perbedaan data dilakukan dengan menggunakan analisis Anova Faktor Tunggal yang sebelumnya diuji normalitas data menggunakan Kolmogorov-Smirnov Test dan Shapiro-Wilk Test, dan keseragaman varian diuji dengan Levene's Test. Kemudian analisis lanjut (Post Hoc Test) dengan menggunakan Tukey HSD Test. Data yang telah dianalisis selanjutnya disajikan dalam bentuk tabel dan grafik.

\section{HASIL DAN PEMBAHASAN \\ Respons Tingkah Laku Ikan Zebra Blactail (Dascyllus melanurus)}

Setelah minyak cengkeh disemprotkan ke dalam akuarium yang telah berisi ikan Zebra blacktail, terlihat gerakan renang ikan mulai mencapai Tahapan Terpengaruh (TT) dengan gerakan yang lebih cepat dari gerakan normal. 
Akan tetapi lama kelamaan terlihat gerakan ikan mulai melambat dan semakin lambat dibandingkan gerakan renang ikan yang normal (ikan kontrol). Kemudian sampai pada tahapan selanjutnya yaitu Tahapan Keseimbangan Terganggu (TKT), ditandai dengan gerakan ikan yang tidak menentu arahnya (oleng), posisi tubuhnya juga tidak stabil dimana terlihat berenang dengan posisi badan terbalik, vertikal atau miring. Setelah beberapa lama, ikan kemudian tidak bergerak, gerakan tubuhnya secara keseluruhan berhenti, dan pada akhirnya ikan jatuh ke dasar akuarium, yang merupakan Tahapan Pingsan (TP). Setelah mencapai TP, ikan kemudian dipindahkan ke akuarium pemulihan yang berisi air laut yang bersih untuk proses pemulihan. Pada akuarium pemulihan, terlihat ikan masih belum bergerak, kemudian berangsur-angsur mulai menggerakkan sirip dan ekornya meskipun masih terlihat sangat lemah, dan pada akhirnya ikan dapat berenang dengan normal kembali dengan posisi badan yang normal (berenang seperti halnya ikan kontrol), yang disebut Tahapan Pulih (TPI). Waktu yang dibutuhkan untuk melewati tahapan-tahapan tersebut dapat dilihat pada Tabel 2 dan Gambar 1.

Berdasarkan Tabel 2, terlihat bahwa waktu induksi terlama terdapat pada konsentrasi $20 \mathrm{ppm}$ dengan waktu rata-rata pada saat terpengaruh 34,67 detik, waktu rata-rata pada saat keseimbangan terganggu 121,33 detik dan waktu rata-rata pada saat pingsan 321,33 detik. Sedangkan waktu induksi tercepat terdapat pada konsentrasi $60 \mathrm{ppm}$ dengan waktu rata-rata pada saat terpengaruh 7,33 detik, pada saat keseimbangan terganggu 14,33 detik dan pada saat pingsan 28,33 detik. Waktu yang dibutuhkan oleh ikan zebra blacktail untuk sampai pada tahapan TT, TKT, TP dan TPI pada setiap konsentrasi minyak cengkeh (20-60 ppm) masing-masing adalah rata-rata berkisar 7,33-34,67 detik; 14,33121,33 detik; 28,33-321,33 detik; dan 80,67188,33 detik.

Gambar 1 menunjukkan bahwa semakin tinggi konsentrasi minyak cengkeh, waktu yang dibutuhkan untuk mencapai tahapan TT, TKT, dan TP cenderung lebih cepat, dimana pada konsentrasi 20 ppm, ikan Zebra blacktail membutuhkan waktu rata-rata untuk mencapai TT, TKT dan TP masing-masing 34,67 detik; 121,33 detik; dan 321,33 detik sedangkan pada konsentrasi 60 ppm hanya membutuhkan waktu masing-masing rata-rata 7,33 detik; 14,33 detik; dan 28,33 detik.

Menurut Prasetyawati (1994), kondisi pingsan adalah kondisi tidak sadar yang dihasilkan oleh proses terkendali dari sistem saraf pusat yang mengakibatkan turunnya kepekaan terhadap rangsangan luar dan rendahnya respons gerak dari rangsangan tersebut. Pingsan atau mati rasa pada ikan berarti sistem saraf yang kurang berfungsi. Proses pembiusan menurut Wright and Hall (1961) meliputi tiga tahap :

1. Berpindahnya bahan pembius dari lingkungan ke dalam muara pernafasan organisme.

2. Difusi membran di dalam tubuh yang menyebabkan terjadinya penyerapan bahan pembius ke dalam darah.

3. Sirkulasi darah dan difusi jaringan menyebarkan substansi tersebut ke seluruh tubuh.

Hasil penelitian ini menunjukkan pada detik ke-0 setelah paparan, aktivitas ikan terlihat masih dalam keadaan normal. Hal tersebut karena eugenol dalam minyak cengkeh belum sepenuhnya berpindah dari lingkungan (media air dalam akuarium) ke dalam alat pernafasan pada ikan. Pengaruh minyak cengkeh pada ikan Zebra blacktail mulai terlihat beberapa saat setelah penyemprotan dimana gerakan ikan mulai terlihat berenang lebih cepat dari biasanya sampai akhirnya gerakannya mulai melambat (TT). TT ikan Zebra blacktail terjadi pada detik ke-34,67 untuk perlakuan konsentrasi $20 \mathrm{ppm}$; detik ke-32 untuk perlakuan $30 \mathrm{ppm}$; detik ke-11 untuk perlakuan $40 \mathrm{ppm}$, detik ke-10 untuk perlakuan 50 ppm dan detik ke-7,33 untuk perlakuan 60 ppm.

Setelah melalui TT, gerakan ikan mulai tidak menentu arahnya, posisi badan ikan di dalam air juga terlihat tidak normal, gerakan ikan mulai tidak terkendali (berenang dengan posisi badan terbalik, vertikal atau miring). Tahapan ini merupakan TKT, dimana ikan mencapai tahapan ini terjadi lebih cepat pada konsentrasi yang paling tinggi (60 ppm) yaitu pada detik ke-14,33.

Tahapan selanjutnya adalah pergerakan ikan semakin melemah, pergerakan sirip dan ekor semakin lambat, begitu juga dengan pergerakan operculum sangat lambat, ikan cenderung berada di dasar akuarium dan pada akhirnya terlihat tidak ada lagi pergerakan (TP). Ikan mencapai tahap ini paling cepat pada konsentrasi 60 ppm, yaitu hanya pada detik ke28,33 , sedangkan waktu terlama pada konsentrasi 20 ppm, yaitu pada detik ke-321,33.

Peningkatan konsentrasi minyak cengkeh yang diberikan menyebabkan percepatan waktu ikan Zebra blacktail mencapai beberapa tahapan sampai akhirnya pingsan (TP). Hal ini disebabkan karena semakin tinggi konsentrasi 
Tabel 1 Tahapan tingkah laku ikan Zebra blacktail setelah dipaparkan minyak cengkeh yang dimodifikasi dari Summerfelt and Smith (1990), Woolsey et al. (2004), Subandi (2004) dan Rahim et al. (2013)

\begin{tabular}{|c|c|c|}
\hline No. & Tahapan & Tingkah Laku \\
\hline 1. & Terpengaruh & $\begin{array}{l}\text { a. Berenang lebih cepat dari normalnya (pada saat terkena } \\
\text { semprotan). } \\
\text { b. Kemudian gerakan ikan menjadi lambat (lebih lambat dari } \\
\text { normalnya). }\end{array}$ \\
\hline 2. & $\begin{array}{l}\text { Keseimbangan } \\
\text { terganggu }\end{array}$ & $\begin{array}{l}\text { a. Arah pergerakan ikan sudah tidak menentu (oleng) } \\
\text { b. Posisi badan ikan di dalam air sudah tidak normal (berenang } \\
\text { dengan posisi badan terbalik, vertical atau miring). }\end{array}$ \\
\hline 3. & Pingsan & $\begin{array}{l}\text { a. Semua gerakan ikan terhenti. } \\
\text { b. Ikan akan jatuh ke dasar. }\end{array}$ \\
\hline 4. & Pulih & $\begin{array}{l}\text { a. Posisi badan ikan di dalam air kembali normal, } \\
\text { b. dapat berenang secara normal kembali. }\end{array}$ \\
\hline
\end{tabular}

Tabel 2 Rata-rata waktu induksi dan waktu pulih ikan zebra blacktail setelah dipaparkan minyak cengkeh beberapa konsentrasi.

\begin{tabular}{|c|c|c|c|c|}
\hline \multirow{2}{*}{$\begin{array}{l}\text { Konsentrasi Minyak } \\
\text { Cengkeh (ppm) }\end{array}$} & \multicolumn{3}{|c|}{ Rata-rata Waktu Induksi (dtk) } & \multirow{2}{*}{$\begin{array}{c}\text { Rata-rata } \\
\text { Waktu Pulih } \\
\text { TPI (dtk) }\end{array}$} \\
\hline & TT & TKT & TP & \\
\hline 20 & 34,67 & 121,33 & 321,33 & 188,33 \\
\hline 30 & 32 & 76 & 160,33 & 147,33 \\
\hline 40 & 11 & 22,67 & 44,33 & 80,67 \\
\hline 50 & 10 & 20,67 & 42,67 & 102,33 \\
\hline 60 & 7,33 & 14,33 & 28,33 & 145,67 \\
\hline
\end{tabular}

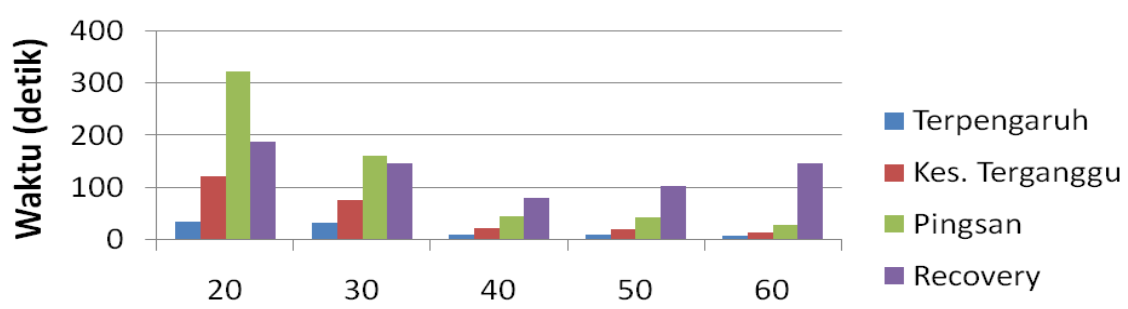

Konsentrasi Minyak Cengkeh (ppm)

Gambar 1 Rata-rata Waktu yang Dibutuhkan oleh Ikan Zebra blacktail untuk mencapai Tahapan Terpengaruh (TT), Keseimbangan Terganggu (TKT), Pingsan (TP) dan Pulih (TPI) Setelah Paparan Minyak Cengkeh Beberapa Konsentrasi $(n=3)$

maka semakin cepat proses penyerapan zat anaestesi (eugenol) oleh darah yang kemudian tersebar ke seluruh bagian tubuh ikan. Zat tersebut akan menghambat pembentukan asetilkolinesterase sehingga menurunkan kerja mediator kimia. Akibatnya proses respirasi dan metabolisme pada ikan Zebra blacktail mengalami penurunan. Hal tersebut akan menyebabkan ikan Zebra blacktail pingsan. Eugenol sebagai zat aktif dari minyak cengkeh merupakan senyawa fenolat yang memiliki gugus alkohol, yang merupakan bahan antiseptik yang dapat melemahkan syaraf dan mengganggu sistem syaraf (Hart 1990).

Hal menarik yang diamati dalam penelitian ini adalah gerakan-gerakan ikan yang jauh lebih tenang pada setiap tahapan-tahapan anastesi setelah ikan dipaparkan minyak cengkeh sampai ikan pada akhirnya pingsan. Berbeda dengan bahan anestesi yang lain, seperti sianida, dimana sesaat setelah pemaparan sianida, ikan akan bereaksi lebih keras dengan gerakan yang memberontak (Kasmi 2012). Pada penelitian ini dimana difokuskan pada tujuan untuk penangkapan ikan di terumbu karang, gerakan ikan setelah terpapar dan keluar dari celah karang sangat mempengaruhi proses penangkapan. Apabila ikan yang terpapar lebih tenang setelah keluar dari celah karang akan memudahkan proses penangkapannya sehingga tanpa alat bantu penangkapan, ikan dapat ditangkap dengan mudah. Berbeda bila gerakan ikan yang terpa- 
par lebih keras (memberontak, mengelepargelepar) setelah keluar dari celah karang menyebabkan lebih sulit ditangkap dengan tangan sehingga membutuhkan alat bantu lain dalam proses penangkapannya. Hal yang sama juga telah dilaporkan oleh Munday and Wilson (1997) yang menyatakan bahwa ikan yang dipaparkan minyak cengkeh menunjukkan gerakan yang lebih tenang dibandingkan bahan anestesi yang lain, seperti quinaldine, MS-222, benzocaine dan 2-phenoxyethanol, dimana bahan-bahan anestesi tersebut merupakan bahan anestesi yang sangat terkenal dan populer yang digunakan secara luas untuk membius ikan. Hal yang sama juga telah dilaporkan oleh Munday and Wilson (1997) yang menyatakan bahwa ikan yang dipaparkan minyak cengkeh menunjukkan gerakan yang lebih tenang dibandingkan bahan anestesi yang lain, seperti quinaldine, MS-222, benzocaine dan 2-phenoxyethanol. Bahan-bahan anestesi tersebut merupakan bahan anestesi yang sangat terkenal dan populer yang digunakan secara luas untuk membius ikan.

Setelah pingsan, ikan kemudian dipindahkan ke akuarium pulih dan diamati tingkah lakunya dengan kamera video. Pada tahapan ini, ikan sedikit demi sedikit mulai melakukan pergerakan, namun pergerakannya masih sangat lambat. Gerakan siripnya juga sudah mulai terlihat meskipun masih sangat lambat. Waktu pulih dihitung mulai pada saat ikan dipindahkan ke akuarium pulih sampai ikan berenang secara normal kembali dan hasilnya dapat dilihat pada Tabel 2 dan Gambar 1.

Grafik pada Gambar 1 menggambarkan terjadinya peningkatan waktu pulih pada konsentrasi lebih rendah lalu terjadi penurunan waktu pulih pada konsentrasi lebih tinggi dengan membentuk pola $U$ atau J. Fenomena kurva grafik yang berpola $U$ atau berpola $J$ ini disebut fenomena hermosis, dimana terjadi disfungsi (penurunan) pada konsentrasi rendah dan stimulasi pada konsentrasi tinggi, ataupun sebaliknya stimulasi pada konsentrasi rendah dan disfungsi pada konsentrasi tinggi dengan pola U terbalik (Calabrese dan Baldwin 2001).

Proses pulih adalah proses dikeluarkannya zat-zat anestesi dari dalam tubuh ikan. Air diserap oleh insang dan masuk secara difusi ke dalam tubuh. Oksigen yang terkandung dalam air tersebut masuk ke dalam darah dan mengangkut eugenol dari seluruh jaringan tubuh termasuk otak. Eugenol diangkut dan dikeluarkan kembali melalui insang (Ferreira et al. 1984). Dalam hal ini, proses pulih pada konsentrasi yang rendah berlangsung lama diduga karena zat eugenol yang diserap oleh ikan masuk sedikit-demi sedikit namun jumlahnya terakumulasi ke seluruh tubuh termasuk otak. Akibatnya, pada proses pulih, air yang mengandung oksigen, yang masuk ke dalam tubuh membutuhkan waktu yang lama pula untuk mengangkut sisa-sisa dari zat eugenol yang terdapat dalam tubuh ikan.

Saat konsentrasi minyak cengkeh ditingkatkan, waktu pulih yang dibutuhkan menjadi cepat. Hal ini diduga karena pada saat oksigen mengangkut eugenol dari dalam tubuh ikan dan pengaruh zat anestesi mulai berkurang, bersamaan dengan itu proses metabolisme dan kebutuhan oksigen untuk respirasi juga semakin meningkat. Kondisi ini mengakibatkan semakin banyak konsentrasi minyak cengkeh yang akan dikeluarkan dari dalam tubuh, sehingga semakin cepat pula laju respirasi karena kebutuhan oksigen yang juga banyak (Wibowo 1993). Peningkatan laju respirasi dan kebutuhan oksigen inilah yang diduga membuat proses pulih semakin cepat.

Namun pada saat konsentrasi minyak cengkeh semakin ditingkatkan, waktu pulih kembali menjadi lebih lama. Hal ini diduga karena efek hermotik dari zat anestetik minyak cengkeh tersebut. Ketidakmampuan toleransi metabolisme dari ikan zebra menyebabkan pengaruh disfungsi atau penurunan fungsi kerja di dalam tubuh ikan zebra. Penurunan fungsi kerja organ menyebabkan gangguan pada proses metabolisme dan laju respirasi di dalam tubuh (Wibowo 1993). Gangguan proses metabolisme dan respirasi inilah yang menghambat proses pemulihan menjadi lebih lama. Menurut Chingran (1985), dosis bahan anestesi yang berlebihan cenderung menjadi racun, membahayakan ikan dan dapat menimbulkan efek kematian karena mengganggu dan menghentikan aktifitas metabolisme dalam tubuh.

Pada beberapa kasus, fenomena hermotik terjadi karena adanya kemampuan toleransi metabolisme beberapa spesies pada zat-zat kimia tertentu, misalkan efek nikotin dan narkotik pada manusia. Pengaruh zat-zat kimia tertentu pada umumnya akan meningkatkan stimulasi kerja metabolisme di dalam tubuh. Namun pada kondisi tertentu dimana kadar zat kimia telah melebihi batas kemampuan fungsi organ maka pemberian zat kimia yang terus menerus dalam kadar konsentrasi lebih tinggi akan mengakibatkan efek disfungsi organ dalam tubuh (Calabrase dan Baldwin 2001).

\section{Waktu Induksi dan Waktu Pulih Ikan Zebra blacktail (Dascyllus melanurus)}

Waktu induksi ikan Zebra blacktail (Dascyllus melanurus) dihitung mulai dari akuarium 
yang berisi ikan tersebut disemprotkan minyak cengkeh sampai ikan tersebut mengalami tahapan pingsan (tidak dapat bergerak lagi). Tahapan-tahapan yang diamati sebelum ikan terinduksi adalah sesaat setelah disemprotkan minyak cengkeh, ikan memberi respons awal dengan gerak renang yang cepat lalu kecepatan renangnya mulai melambat (Tahapan Terpengaruh). Setelah itu, ikan mengalami gerakan yang tak menentu arahnya dengan posisi badan di dalam air tidak normal (mengalami gangguan keseimbangan). Dalam kondisi tersebut, terlihat ikan bergerak dengan posisi terbalik, vertikal atau miring. Kecepatan renang ikan juga semakin berkurang pada tahapan ini (Tahapan Keseimbangan Terganggu) dan pada akhirnya ikan tidak dapat lagi melakukan pergerakan (Tahapan Pingsan). Waktu pulih dihitung mulai pada saat ikan dimasukkan ke dalam akuarium pulih sampai gerakan ikan mulai pulih kembali yang ditandai dengan gerakan ikan yang sama dengan kontrol (sebelum dipaparkan minyak cengkeh). Waktu induksi dan waktu pulih ikan Zebra blacktail (Dascyllus melanurus) dapat dilihat pada Gambar 2.

Berdasarkan Gambar 2 telah terjadi penurunan drastis waktu induksi dari $20 \mathrm{ppm}$ sampai $40 \mathrm{ppm}$ yang diduga karena rendahnya konsentrasi anestesi yang menyebabkan lambatnya daya impuls asetilkolin yang menurunkan kinerja organ respirasi dan metabolisme pada ikan zebra sehingga ikan zebra membutuhkan rentan waktu yang lebih lama untuk dapat pingsan pada kisaran konsentrasi antara $20 \mathrm{ppm}$ hingga $40 \mathrm{ppm}$. Selain itu, sifat fisiologi ikan zebra yang masih toleran terhadap pengaruh minyak cengkeh pada kisaran konsentrasi yang lebih rendah juga dapat mempengaruhi lamanya waktu pingsan.

Penurunan yang tidak terlalu berbeda terlihat pada konsentrasi $40 \mathrm{ppm}$ sampai 60 $\mathrm{ppm}$. Hal ini diduga karena konsentrasi $40 \mathrm{ppm}$ sampai $60 \mathrm{ppm}$ merupakan konsentrasi yang cukup tinggi dari batas kisaran konsentrasi yang dapat ditolerir oleh ikan zebra. Konsentrasi yang begitu tinggi membuat proses difusi anestesi dalam aliran darah melalui insang terjadi sangat cepat, sehingga waktu induksi relatif sama pada beberapa konsentrasi yang tinggi. Menurut Hunn (1970) dalam Ferreira et al. (1984), efek pembiusan zat anestesi terhadap ikan ditentukan oleh kadar anestesi yang terkandung dalam jaringan otak atau sarafnya.

Hasil Uji ANOVA pada taraf kesalahan 5 $\%(\alpha=0.05)$ untuk waktu induksi (pingsan) menunjukkan bahwa penggunaan minyak cengkeh yang berbeda $(20,30,40,50$ dan 60 ppm) memberikan hasil yang tidak signifikan (tidak berbeda nyata) pada Waktu Pingsan ikan Zebra blacktail $(P>0,05)$. Sedangkan hasil uji ANOVA pada taraf kesalahan $5 \%(\alpha=0.05)$ terhadap Waktu Pulih ikan Zebra blacktail menunjukkan bahwa pada perlakuan dengan konsentrasi minyak cengkeh yang berbeda (20, $30,40,50$ dan 60 ppm) memberikan hasil yang berbeda nyata pada Waktu Pulih ikan Zebra blacktail $(P<0,05)$.

Gambar 2 menunjukkan bahwa konsentrasi minyak cengkeh yang tinggi menyebabkan waktu induksi ikan Zebra blacktail (Dascyllus melanurus) cenderung semakin cepat, dimana pada konsentrasi minyak cengkeh $60 \mathrm{ppm}$ ikan lebih cepat mencapai tahapan pingsan, yaitu rata-rata hanya 28,33 detik sedangkan pada konsentrasi 20 ppm, ikan mencapai tahapan pingsan setelah waktu rata-rata 321,33 detik. Namun, berdasarkan hasil uji statistik tidak terjadi perbedaan yang signifikan waktu untuk mencapai pingsan antara beberapa konsentrasi minyak cengkeh yang disemprotkan. Sebaliknya waktu pulih ikan berdasarkan hasil uji statistik menunjukkan adanya perbedaan yang signifikan antara waktu pulih ikan Zebra blacktail pada konsentrasi minyak cengkeh yang berbeda.

Penurunan waktu induksi pada penelitian ini dengan meningkatnya konsentrasi minyak cengkeh mengikuti pola umum yang telah diperoleh pada penelitian-penelitian sebelumnya (Soto dan Burhanuddin 1995; Munday and Wilson 1997; Keene et al. 1998; Griffiths 2000; Woody et al. 2002; Cunha 2006; Rahim et al. 2013), pada spesies ikan yang berbeda. Rahim et al. (2013) telah melakukan penelitian pada ikan injel biru-kuning dan melaporkan bahwa waktu induksi menurun dengan peningkatan konsentrasi minyak cengkeh. Cunha (2006) telah melaporkan pada 7 jenis ikan karang di daerah tropis bahwa waktu induksi dan waktu pulih ke-7 jenis ikan karang tersebut berbeda. Namun demikian, secara keseluruhan waktu induksi mempunyai kecenderungan lebih cepat dengan meningkatnya konsentrasi minyak cengkeh. Sebaliknya waktu pulih cenderung lebih lama dengan meningkatnya konsentrasi. Hasil yang sama juga telah dilaporkan oleh Griffiths (2000) pada 8 jenis ikan intertidal yang berbeda.

Waktu induksi dan waktu pulih setiap jenis ikan yang dipaparkan bahan anestesi berbeda-beda. Hal ini dipengaruhi oleh konsentrasi bahan anestesi dan spesies. Menurut Gunn (2001), ikan-ikan dengan ruang insang yang besar lebih efisien dalam menyerap bahan-bahan anestesi. Musim, ukuran tubuh, aktivitas, kesehatan, umur dan jenis kelamin juga mempengaruhi kecepatan induksi dan 
proses pemulihannya. Penelitian ini hanya menggunakan satu spesies dengan ukuran tubuh yang hampir sama sehingga faktor-faktor yang mempengaruhi kecepatan induksi dan proses pemulihan ini dapat diabaikan.

Berdasarkan data waktu induksi dan waktu pulih ikan zebra, dapat terlihat bahwa konsentrasi minyak cengkeh 40 ppm merupakan konsentrasi yang lebih efektif dalam proses penangkapan ikan untuk memingsankan ikan dengan waktu induksi berkisar 40-48 detik (paling kurang dari 3 menit) dan waktu pulih berkisar 72-91 detik (paling kurang dari 5 menit). Meskipun demikian, pada Tabel 2 dan Gambar 2 menunjukkan terdapat perbedaan waktu induksi yang tidak terlalu besar antara 40 ppm, $50 \mathrm{ppm}$ dan $60 \mathrm{ppm}$. Namun penentuan waktu induksi yang optimal sebaiknya dengan mengambil konsentrasi yang paling rendah dari beberapa konsentrasi yang memiliki efek waktu pulih yang hampir sama. Dengan kata lain, penentuan konsentrasi yang efektif tidak terlepas dari pertimbangan efisiensi biaya. Sesuai dengan Marking dan Meyer (1985), bahwa zat anestesi yang ideal memiliki waktu induksi kurang dari 3 menit dan waktu pulih yang relatif singkat, yakni 5 menit atau kurang. Meskipun demikian, penentuan konsentrasi yang lebih efektif masih memerlukan pengkajian yang lebih jauh dalam hal peruntukkannya. Misalnya untuk digunakan dalam penangkapan ikan, transportasi ataupun sebagai bahan alternatif ramah lingkungan pengganti sianida. Selain itu, masih banyak faktor yang perlu dikaji lebih lanjut, misalnya dalam hal dampaknya terhadap ikan-ikan non target, ikan target maupun terhadap habitat ikan tersebut yakni terumbu karang. Dalam hal penggunaan minyak cengkeh sebagai alat bantu penangkapan bukan hanya dengan melihat efektivitasnya dalam menginduksi ikan, tetapi perlu mempertimbangkan beberapa faktor, seperti bagaimana kondisi ikan target setelah penangkapan, ikan non-target yang ada di terumbu karang dan karang itu sendiri.

Beberapa penelitian mendapatkan hasil konsentrasi optimal yang sama, seperti Hajek et al. (2006) melaporkan bahwa konsentrasi optimal anestesi minyak cengkeh terhadap ikan mas (Cyprinus carpio) adalah 40 ppm dengan waktu induksi kurang dari 3 menit dan waktu pulih kurang dari 4 menit. Zaikov et al. (2008) telah melaporkan bahwa konsentrasi optimal untuk ikan catfish (Silurus glanis $L$ ) adalah 40 ppm, Inoue (2003) menunjukkan bahwa konsentrasi optimal untuk ikan brycon (Brycon cephalus) adalah 40 ppm. Griffiths (2000) telah melaporkan bahwa secara umum konsentrasi yang paling sesuai pada 8 spesies ikan intertidal yang diamati di Australia adalah 40 $\mathrm{mg} / \mathrm{L}$ dimana rata-rata waktu induksi $<180$ detik dan rata-rata waktu pulih $<300$ detik.

Beberapa penelitian lainnya, pada jenis ikan yang berbeda, respons terhadap induksi bahan anestesi juga akan berbeda. Misalnya konsentrasi optimal untuk ikan klon (Amphiprion percula) adalah $20 \mathrm{ppm}$ dengan waktu induksi 162 detik dan waktu pulih 309 detik (Ratnasari 2002). Konsentrasi optimal untuk ikan tombak (Esox lucius) adalah 60 ppm dengan waktu induksi sektiar 7 menit dan waktu pulih sekitar 4 menit (Zaikov et al. 2008). Konsentrasi optimal untuk ikan trout (Oncorhynchus mykiss) adalah 30 ppm (Mavadati 2011). Keene (1998) telah merekomendasikan dosis eugenol pada juvenil rainbow trout untuk mencapai tahapan pingsan adalah 40-60 ppm selama 3-6 menit. Cunha (2006) telah menyarankan konsentrasi 20 ppm minyak cengkeh sebagai pedoman umum ketika menganastesi ikan-ikan karang dan pada spesies-spesies tertentu menggunakan konsentrasi yang lebih tinggi. Lebih lanjut dinyatakan bahwa direkomendasikan konsentrasi yang paling rendah selama sampling lapangan demi memaksimalkan keamanan, mengurangi kematian dan stres pada ikan. Penelitian Walsh and Pease (2002) menyatakan bahwa minyak cengkeh direkomendasikan untuk menginduksi ikan anguillid eels karena minyak cengkeh efektif, relatif lebih murah dan resiko yang kecil pada kesehatan manusia. Waterstrat (1999) telah menyatakan pula bahwa konsentrasi minyak cengkeh $100 \mathrm{mg} / \mathrm{L}$ efektif pada ikan Ictalurus punctatus. Akbulut et al. (2011) menyatakan bahwa minyak cengkeh dapat digunakan sebagai anestesi yang efektif pada larva ikan Russian sturgeon (Acipenser gueldenstaedtii).

Beberapa penelitian pada organisme perairan telah dilakukan oleh Coyle et al. (2005) yang menyarankan konsentrasi minyak cengkeh $100 \mathrm{mg} / \mathrm{L}$ untuk menganestesi udang Macrobrachium rosenbergii. Woody et al. (2002) menyatakan bahwa konsentrasi minyak cengkeh $50 \mathrm{mg} / \mathrm{L}$ direkomendasikan untuk menginduksi sockeye salmon dengan kisaran panjang $400-550 \mathrm{~mm}$ pada temperatur $9-10^{\circ} \mathrm{C}$. Seol et al. (2007) juga menyatakan bahwa konsentrasi minyak cengkeh $200 \mathrm{mg} / \mathrm{L}$ dapat menginduksi dengan cepat Octopus minor.

Hasil penelitian ini dan penelitianpenelitian sebelumnya telah menunjukkan bahwa waktu induksi ikan yang dipaparkan minyak cengkeh lebih cepat meskipun dengan konsentrasi yang lebih rendah jika dibandingkan dengan bahan anaestesi ikan yang telah dikenal dan populer pada beberapa negara. Menurut Griffiths (2000), meskipun 


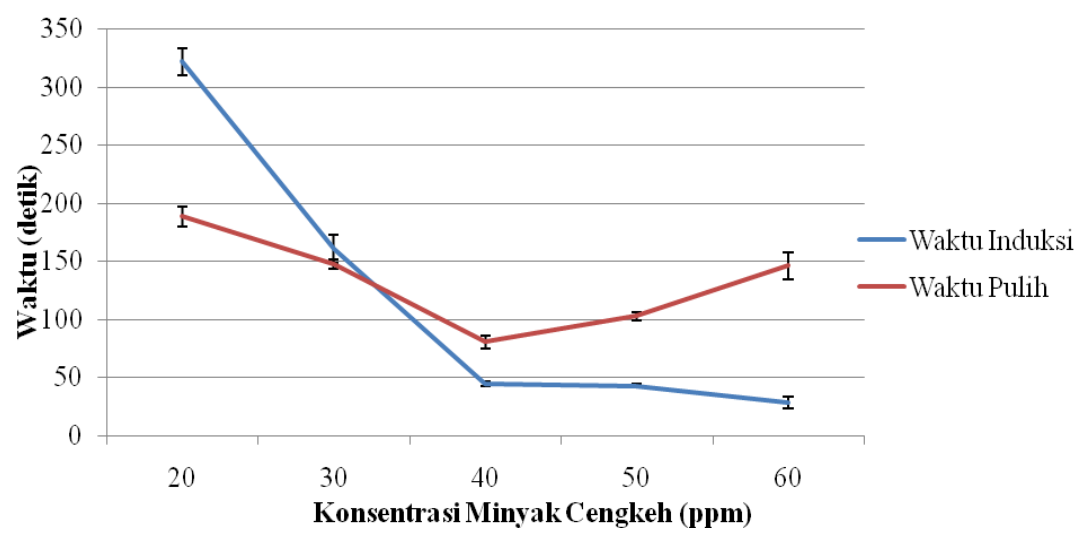

Gambar 2 Rata-rata waktu induksi dan waktu pulih ikan zebra blacktail setelah dipaparkan minyak cengkeh beberapa konsentras

rata-rata waktu induksi dan waktu pulih ikan yang dipaparkan minyak cengkeh relatif lebih cepat, namun cukup untuk mengidentifikasi dan mencatat informasi biologi ikan.

\section{KESIMPULAN}

Meningkatnya konsentrasi minyak cengkeh yang dipaparkan pada ikan Zebra blacktail menyebabkan waktu induksi cenderung lebih cepat. Konsentrasi optimum minyak cengkeh untuk ikan zebra blacktail (Dascyllus melanurus) pada proses penangkapan ikan adalah 40 ppm dengan waktu induksi berkisar 40-48 detik dan waktu pulih berkisar 72-91 detik.

\section{SARAN}

Untuk aplikasi minyak cengkeh sebagai alternatif sianida dalam penangkapan, masih dibutuhkan kajian yang lebih dalam, khususnya efek minyak cengkeh terhadap kualitas ikan target, organisme non-target dan ekosistem terumbu karang. Selain itu, penelitian secara langsung di lapangan masih sangat dibutuhkan untuk membuktikan efektivitas minyak cengkeh sebagai alat bantu penangkapan ikan di ekosistem terumbu karang.

\section{DAFTAR PUSTAKA}

Akbulut B, Cavdar Y, Cakmak E, Aksungur N. 2011. Use of Clove Oil to Anaesthetize Larvae of Russian Sturgeon (Acipenser gueldenstaedtii). Journal of Applied lchthyology. 27: 618-621.

Calabrese EJ, Baldwin LA. 2001. The Frequency of U-Shaped Doseresponsses in the Toxicological Literature. Toxicol Sci Journal. 62: 330 -338 .
Cervino JM, Hayes RL, Honovich M, Goreau TJ, Jones S, Rubec PJ. 2003. Changes in Zooxanthellaee Density, Morphology, and Mitotic Index in Hermatypic Corals and Anemones Exposed to Cyanide, Journal of Mar. Pollut. Bull. 46: 573-586.

Chingran VG, Pullen RSV. 1985. A Hatchery Manual for the Common Carp Chinese, and Indian Major Corps. ICLARM. Studies and Recew 11. 7880.

Cho GK, Heath DD. 2000. Comparison of Tricaine Methanesulphonate (MS-22) and Clove Oil Anaesthesia Effects on Physiology of Juvenile Chinook Salmon Oncorhynchus Tshawytscha (Walbaum). Journal of Aquaculture Research. 31: 357-546.

Coyle SD, Dasgupta S, Tidwell JH, Beavers T, Bright LA, Yasharian DK. 2005. Comparative Efficacy of Anesthetics for the Freshwater Prawn Macrobrachium rosenberrgii. Journal of the World Aquaculture Society. 36(3): 282-290.

Cunha FEA, Rosa IL. 2006. Anaesthetic Effects of Clove Oil on Seven Species of Tropical Reef Teleosts. Journal of Fish Biology. 69(5): 15041512.

Ferreira JT, Schoonbee HJ, Smith GL. 1984. The Uptake of the Anesthetic Benzoncaine Hydrochloride by the Gills and the Skin of Three Freshwater Fish Spesies. Journal of Fish Biology. 25(1).

Griffiths SP. 2000. The Use of Clove Oil as an Anaesthetic and Method for Sampling 
Intertidal Rockpool Fishes. Journal of Fish Biology. 57(6): 1453-1464.

Gunn E. 2001. Floundering in the Foiber of Fish Anaestesia. P211.

Hart H. 1990. Kimia Organik. Terjemahan Seminar. Penerbit Erlangga. Jakarta.

Hajek G, Klyszejko B. 2006. The Anesthetic Effect of Clove Oil on Common Carp Cyprinus carpio L. ACTA Icthhyologica et piscatorial. Poland. 36 (2): 93 - 97

Inoue LA. 2003. Clove Oil As Anaesthetic for Juveniles of Matrinxã Brycon cephalus, Ciência Rural. Santa Maria.

Jones RJ, Steven AL. 1997. Effects of Cyanide on Corals in Relation to Cyanide Fishing on Reefs, Journal of Mar. Freshw. Res. 48: 517-522.

Jones, Guldberg H. 1999. Effects of Cyanide on Coral Photosynthesis: Implications for Identifying the Cause of Coral Bleaching and for Assessing the Environmental Effects of cyanide fishing. Journal of Mar. Ecol. Prog. Ser. 177: 83-91.

Keene JL, Noakes DG, Moccia RD, Soto CG. 1998. The Efficacy of Clove Oil as an Anaesthetic for Rainbow Trout, Oncorhynchus mykiss (Walbaum). Journal of Aquaculture Research. 29: 89-101.

Kasmi, M., 2012. Status Pemanfaatan dan Strategi Pengelolaan Berkelanjutan Ikan Hias Injel Napoleon (Pomacanthus xanthometopon) di Perairan Sulawesi Selatan. Disertasi Program Pascasarjana Unhas, Makassar.

Marking LL, Meyer FP. 1985. Are Better Anesthetics Needed in Fisheries?. Fisheries. 10: 2-5

Mavadati. 2011. Comparison of Effect of Clove Oil and 2-Phenoxyethanol on Serum Biochemical Parameters in Oncorhynchus mykiss. Word Journal of Fish and Marine Science. 3(4): 318322

Munday PL, Wilson SK. 1997. Comparative Efficacy of Clove Oil and Other Chemicals in Anaesthetization of Pomacentrus amboinensis, a Coral Reef Fish. Journal Fish Biology. 51: 931-938.

Prasetyawati R. 1994. Studi Penenangan dan Pemingsanan Ikan Gurame
(Osphoronemus gouramy Lac.) untuk Transportasi Hidup dalam Media Tanpa Air. Skripsi. Fakultas Perikanan, IPB. Bogor

Rahim SW, Nessa MH, Trijuno DD, Djawad MI. 2013. Efektivitas Minyak Cengkeh Sebagai Alat Bantu Penangkapan Ikan Injel Biru Kuning (Centropyge bicolor). Prosiding. Seminar Nasional Perikanan dan Kelautan X, Universitas Gadjah Mada. Yogyakarta.

Ratnasari D. 2002. Pengaruh Penggunaan Minyak Cengkeh Terhadap Ikan Klon (Amphiprion percula) dan Anemon Piring (Heteractis magnifica) sebagai Alternatif Pengganti Potasium Sianida. Skripsi, Jurusan Budidaya Perairan. IPB. Bogor.

Rubec PJ, Cruz F, Pratt V, Oellers R, McCullough B, Lallo F. 2001. Cyanide-Free Net-Caught Fish for the Marine Aquarium Trade, Journal of Aquar. Sci. Conserv. 3: 37-51

Seol DW, Lee J, Im SY, Park IS. 2007. Clove Oil as an Anaesthetic for Common Octopus (Octopus minor, Sasaki). Journal of Aquaculture Research. 38: 45-49.

Soto CG, Burhanuddin. 1995. Clove Oil as a Fish Anaesthetic for Measuring Length and Weight of Rabbitfish (Siganus lineatus). Journal of Aquaculture. 135: 149-152.

Subandi N. 2004. Pengembangan Metode Penyidikan IImiah untuk Pembuktian Kasus-Kasus Penangkapan Ikan dengan Bahan Peledak dan Sianida. Disertasi. Sekolah Pascasarjana IPB, Bogor.

Summerfelt RC, Smith LS. 1990. Anesthesia, Surgery and Related Techniques. In: Methods for Fish Biology (ed. By C.B. Schreck \& P.B. Moyle). American Fisheries Society: 213-272.

WalshCT, Pease BC. 2002. The Use of Clove Oil as an Anaesthetic for the Longfinned Eel, Anguilla reinhardtii (Steindachner). Journal of Aquaculture Research. 33: 627-635.

Waterstrat PR. 1999. Induction and Recovery from Anaestesia in Channel Catfish Ictalurus Punctatus Fingerlings Exposed to Clove Oil. Journal of the World Aquaculture Society. 30(2): 250-255. 
Woody CA, Nelson J, Ramstad K. 2002. Clove Oil as an Anaesthetic for Adult Sockeye Salmon : Field Trials. Journal of Fish Biology. 60: 340-347.

Woolsey J, Holcomb M, Ingermann RL. 2004. Effect of Temperature on Clove Oil Anesthesia in Steelhead Fry. North American. Journal of Aquaculture. 66: 35-41.

Wibowo S, 1993. Penerapan Teknologi Penanganan dan Transportasi Ikan Hidup di Indonesia. Sub BPPL Slipi. Jakarta.
Wright GJ, Hall LW. 1961. Veterinary an Anesthesia and Analgesia. Baillere, Tindal and Cox. London.

Zaikov A, llev I, Hubenova T. 2008. Induction and Recovery from Anesthesia in Pike (Esox lucius) Exposed to Clove Oil. Bulg. Journal of. Agric. Sci. 14: 165170. 